\title{
SELF DIRECTED LEARNING BERBASIS LITERASI DIGITAL PADA MASA PANDEMI COVID-19 DI MADRASAH IBTIDAIYAH
}

\author{
Elya Umi Hanik \\ IAIN Kudus, Kudus, Indonesia \\ elyaumi@iainkudus.ac.id
}

\begin{abstract}
The Implementation of Educational Policy in the Corona Virus Disease Emergency Period, requires educators to make a learning innovation, namely learning self directed learning based on digital literacy. This study aims to discuss 1) the concept of self directed learning, 2) the concept of digital literacy, 3) analysis of self directed learning based on digital literacy based on the co-19 pandemic at Madarasah Ibtidaiyah. This type of research used in this study is a qualitative study of literature approach with technical content analysis, the results of this study are 1) Self directed learning learning is independent learning to increase the responsibilities of students in the learning process. 2) Digital literacy is the knowledge and skills to use digital media, communication tools, or networks in finding, evaluating, using, making information, and using it in a healthy, wise, intelligent, accurate, precise, and law-abiding manner in order to foster communication and interactions in everyday life. 3) implement the implementation of digital literacybased self direct learning during the Covid-19 pandemic, as follows; Provision of Educative Sites as School Community Learning Resources, Use of Educational Applications as School Community Learning Resources and online learning by making learning programs from home that are broadcast
\end{abstract}


through the National TV channel of the Republic of Indonesia by the Ministry of Education and Culture.

Keywords; Self Directed Learning, Digital Literacy, Pandemic Covid-19, Elementary School.

\begin{abstract}
Abstrak
Pelaksanaan Kebijakan Pendidikan dalam Masa Darurat Corona Virus Disease, menuntut pendidik untuk melakukan sebuah inovasi pembelajaran, yaitu pembelejaran self directed learning berbasis literasi digital. Penelitian ini bertujuan untuk membahas 1) konsep pembelajaran self directed learning, 2) konsep literasi digital, 3) analisis self directed learning berbasisi literasi digital pada masa pandemi covid-19 di Madarasah Ibtidaiyah. Jenis penelitian yang digunakan dalam penelitian ini adalah studi kepustakaan pendekatan kualitatif dengan teknis analisis isi, hasil penelitian ini adalah 1)Pembelajaran self directed learning adalah belajar mandiri untuk meningkatkan tanggung jawab peserta didik dalam proses pembelajaran. 2)Literasi digital adalah pengetahuan dan kecakapan untuk menggunakan media digital, alat-alat komunikasi, atau jaringan dalam menemukan, mengevaluasi, menggunakan, membuat informasi, dan memanfaatkannya secara sehat, bijak, cerdas, cermat, tepat, dan patuh hukum dalam rangka membina komunikasi dan interaksi dalam kehidupan sehari-hari. 3)mplementasikan pelaksanaan pembelajaran self direct learning berbasis litersi digital pada masa pandemi Covid-19, sebagai berikut; Penyediaan Situs-Situs Edukatif sebagai Sumber Belajar Warga Sekolah, Penggunaan Aplikasi-Aplikasi Edukatif sebagai Sumber Belajar Warga Sekolah dan pembelajaran daring dengan membuat progam belajar dari rumah yang ditayangkan melalui saluran TV Nasional Republik Indonesia oleh Mendikbud
\end{abstract}

Kata Kunci; Self Directed Learning, Literasi Digital, Pandemi Covid-19, Madrasah Ibtidaiyah. 


\section{A. Pendahuluan}

Dewasa ini berbagai negara telah dikejutkan dengan pandemi covid-19, yang menyebabkan angka kematian tinggi bagi pasien yang terpapar virus. Tentunya ini menjadi permasalahan baru yang harus dihadapi oleh dunia pada masa ini. Sebagai upaya telah dilakuan untuk menanggulangi pandemi ini, diantaranya telah terbentuk kebijakan baru; social distancing, work from home, belajar dari rumah hingga lockdown bagi negara yang terdampak, termasuk bagi negara Indonesia. Indonesia menjadi salah satu negara yang terdampak pandemi covid 19, yang dalam perkembangannya semakin hari semakin cepat menyebar ke sejumlah wilayah yang ada di Indonesia. Oleh karenanya pandemi covid-19 yang menimpa Indonesia pada akhir- akhir ini telah menyebabkan perubahan yang besar dalam berbagai aspek kehidupan mulai dari aspek ekonomi, social, budaya, agama dan tidak lepas juga aspek Pendidikan.

Keharusan dalam melaksanakan kebijakan social distancing, work form home dan belajar dari rumah untuk menghentikan penyebaran covid 19, telah menyebabkan pergeseran paradigma Pendidikan di Indonesia pada masa pandemi ini. Dampak yang sangat nyata dalam dunia Pendidikan, yaitu telah terjadinya disrupsi teknologi sebagai pergeseran arah pembelajaran, dari yang biasanya melaksankaan pembelajaran tatap muka, cecara drastis kini berubah menjadi pembelajaran yang sifatnya daring atau berbasis online tanpa melakukan tatap muka. Hal tersebut tentunya melatar belakangi keluarnya Surat Edaran Nomor 4 Tahun 2020 pada tanggal 24 Maret, oleh Menteri Pendidikan dan Kebudayaan RI sebagai kebijakan pelaksanaan Pendidikan dalam masa darurat Penyebaran Coronavirus Disease.

Dalam surat Edaran Nomor 4 Tahun 2020, terdapat enam point penting kebijakan baru dalam dunia Pendidikan, yang sudah diapaparkan dengan jelas, di antaranya terkait dengan UN, PPDB, Ujian Sekolah dan Lulusan, Kenaikan Kelas, Dana BOS serta hal yang mendasar dari keseluruhan point tersebut ialah merubah 
cara pembelajaran antara Pendidik dan peserta didik dengan melaksanakan kegiatan belajar mengajar dari rumah. Kebijakan belajar dari rumah melalui pembelajaran daring/jarak jauh dilaksanakan untuk memberikan pengalaman belajar yang bermakna bagi siswa, tanpa terbebani tuntutan menuntaskan seluruh capaian kurikulum untuk kenaikan kelas maupun kelulusan. (Mendikbud RI, 2020)

Dengan melihat kebijakan baru tersebut, pendidik seyogyanya berupaya untuk melakukan inovasi dalam kegiatan belajar agar peserta didik tetap bisa melaksanakan tugas belajar di rumah. Sesuai dengan anjuran menteri pendidikan, pembelajaran dilaksanakan dengan cara daring atau jarak jauh. Pendidik dapat memanfaatkan teknologi yang sekarang ini sudah berkembang pesat, diharapkan pembelajaran tidak akan terhambat meskipun tanpa tatap muka. Terdapat beberapa alternatif dalam memanfaat teknologi diantaranya dengan memanfaatkan litersi digital sesuai dengan generasi 4,0. Pemanfaatan literasi digital sebagai bentuk penyesuaian gelombang peradaban keempat yang saat ini dikenal dengan era pendidik 4.0. Perkembangan IPTEK yang sangat pesat menuntut pendidik untuk mengembangkan kompetensinya secara berkelanjutan dengan tujuan agar peserta didik memiliki kompetensi abad 21 yang mampu berfikir kritis, kolaboratif dan komunikatif. Adanya pergeseran arah pendidikan selain dalam hal teknologi pendidikan, tentunya berkaitan dengan model pembelajaran pada abad 21 pembelajaran bukan lagi teacher centered learning akan tetapi student centered learning.

Pembelajaran dengan model student centered learning, akan memberikan ruang yang lebih luas dan bermakna bagi peserta didik dalam mencari pengalaman dan mengkonstruk pengalaman tersebut menjadi pengetahuan baru, peserta didik dengan mandiri mencari hal baru dan juga memiliki control penuh dalam mengembangakan pembelajarannya sendiri, dengan kemandirian peserta didik dalam proses belajar atau self directed learning akan membentuk peserta didik yang lebih kreatif. Dengan 
konsep belajar demikian tentunya menjadi satu langkah solutif di tengah masa pandemi yang terjadi di Indonesia, pembelajaran self directed learning berbasis literasi memberikan warna baru bagi peserta didik dalam belajar, yang tidak dibatasi dengan ruang maupun waktu, peserta didik akan mampu mengeksplore materi pembelajaran lebih luas melalui berbagai jenis literasi digital, sehingga meskipun di masa pandemi saat ini, terdapat keterbatasan tatap muka dalam pembelajaran, hal tersebut bukan menjadi penghalang bagi peserta didik dalam melaksanakan kegiatan belajar, khususnya bagi peserta didik yang berada pada jenjang pendidikan dasar. Berdasarkan permasalahan tersebut, penulis akan membahas; a) konsep pembelajaran self directed learning, b) konsep literasi digital, c) analisis self directed learning berbasisi literasi digital pada masa pandemi covid-19 di Madarasah Ibtidaiyah.

\section{B. Pembahasan}

\section{Metode Penelitian}

Jenis penelitian yang digunakan dalam penelitian ini adalah studi kepustakaan atau literatur review, penelitian yang pengkajiannya dilakukan secara objektif, dan sumber datanya adalah buku- buku literatur, maupun jurnal penelitian yang lazim digunakan dalam penelitian yang pengumpulan datanya melalui kajian kepustakaan. Metode studi literatur berkaitan dengan mengumpulkan data pustaka, membaca dan mencatat serta mengolah bahan penulisan. Jenis penulisan yang digunakan adalah studi literatur yang berkaitan dengan topik atau variabel penelitian. Adapun pendekatan dalam penulisan ini, menggunakan pendekatan kualitatif dengan teknis analisis isi, yaitu menarik kesimpulan dengan mengindentifikasi karakteristik- karakteristik khusus suatu pesan secara objektif dan sistematik. 


\section{Hasil Penelitian}

\section{a. Konsep Pembelajaran Self Directed Learning}

Konsep model pembelajaran Self-Directed Learning atau pembelajaran mandiri merupakan proses belajar yang dilakukan atas inisiatif sendiri. Sebagaimana menurut Plews "Self Direct Learning as a process "in which individuals take the initiative with or without the help of others in diagnosing their learning needs, formulating learning goals, identifying human and material resources for learning, choosing and implementing appropriate learning strategies and evaluating learning outcomes"(Plews, 2017). Bagian yang terpenting dari penggunaan model pembelajaran SDL adalah menerapkan sistem pembelajaran secara mandiri. Sistem pembelajaran ini dapat mengembangkan peserta didik menjadi lebih aktif dan leluasa dalam menentukan apa yang akan dipelajari. Dalam pembelajaran SDL peserta didik atau atau Individu belajar melalui pembelajaran yang diatur sendiri, peserta didik secara mandiri akan terdorong untuk bisa menetapkan tujuan dalam pembelajaran mereka dan berusaha untuk mencapai tujuan yang diinginkan sesuai dengan keinginan peserta didik. Pada proses pelaksanaannya peserta didik akan mencoba berbagai cara untuk mewujudkan tujuan mereka. Hal ini didasari dengan motivasi intenal yang kuat dari peserta didik daripada motivasi eksternal seperti kesadaran dalam hal belajar, kemampuan yang dimiliki, dan sikap mengendalikan maupun mengatur jalannya proses belajar, kesemuanya dilakukan secara mandiri. Self-Directed Learning dapat dipahami sebagai peningkatan pengetahuan, keahlian, prestasi dan pengembangan individu yang diawali dengan inisiatif sendiri menggunakan perencanaan belajar sendiri dan dilakukan sendiri, menyadari kebutuhan belajar sendiri dalam mencapai tujuan belajar dengan cara membuat strategi belajar sendiri serta penilaian hasil belajar sendiri. (Zamnah \& Ruswana, 2018). Adapun karakteristik model pembelajaran self directed learning sebagai berikut; 
1) Peserta didik secara mandiri memiliki usaha yang keras dan rasa tanggung jawab membuat keputusan yang terkait dengan pembelajaran

2) Peserta didik memikli kewenangan dalam melibatkan pemikiran, tindakan ataupun mengelola aktivitas pembelajaran secara mandiri

3) Makna pembelajaran mandiri tidak selalu berarti belajar mandiri di mana pembelajaran berlangsung terpisah dari orang lain; tetapi juga bisa melibatkan teman atau peserta didik yang lain.

4) mengharuskan peserta didik untuk memonitor sendiri proses pembelajaran yang akan terjadi, adanya progress atau tidak dalam sebuah pembelajaran. (Tan, L., \& Koh, 2014)

5) Kontrol aktivitas belajar secara bertahap bergeser dari pendidik ke peserta didik

6) Adanya peran penting motivasi dan kemauan peserta didik. Motivasi akan mendorong keputusan peserta didik untuk berpartisipasi, dan kemauan untuk melaksanakan tugas sampai tercapainya tujuan pembelajaran. (Joshi, Bharat, 2012).

Beberapa point penting yang diamati dalam pembelajaran yang didasarkan pada self directed learning, diantaranya; 1) ada proses yang berorientasi pada tujuan, yaitu, peserta didik memiliki tujuan, 2) peserta didik mengambil inisiatif sendiri dan melaksanakan tugasnya secara mandiri untuk mencapai tujuan, yang berarti sehingga akan muncul sikap bertanggung jawab, 3) peserta didik memiliki kesadaran metakognitif. (Kayacan \& Ektem, 2019).

Secara garis besar, model SDL dibagi menjadi tiga tahapan yaitu planning, monitoring dan evaluating (Song, L \& Hill, 2007) Tahapan ini diawali dengan peserta didik merencanakan aktivitas untuk belajar, merencanakan komponen belajar yang diinginkan serta menentukan target belajar yang ingin dicapai kemudian mengamati dan mengobservasi pembelajaran mereka. Dalam 
190 | Elya Umi Hanik

mengimplementasikan model pembelajaran self direct learning, terdapat beberapa langkah yang harus dipersipakan, diantaranya langkah-langkah tersebut dibagi menjadi enam yaitu preplanning, menciptakan lingkungan belajar yang positif, mengembangkan rencana pembelajaran, mengidentifikasi aktivitas pembelajaran yang sesuai, melaksanakan kegiatan pembelajaran dan mengevaluasi hasil belajar individu. (Richard, 2007). Secara rinci terdapat empat langkah sebelum melaksanakan pembelajaran self directed learning;

1) Pada langkah pertama, peserta didik harus secara khusus menuliskan tentang kebutuhannya belajar secara terperinci agar jelas untuk merencanakan kegiatan belajar.

2) Langkah kedua, merencanakan kegiatan belajar. Pada langkah ini peserta didik harus menjawab sendiri berdasarkan pertanyaan dasar yang telah dirancang

a) Apa tujuan dari saya belajar?

b) Dari mana literatur / data / nara sumber akan tersedia?

c) strategi / metode / teknik yang mana yang sesuai untuk belajar dan mengapa?

d) Berapa lama waktu yang akan dihabiskan dalam proses belajar?

e) Apa yang akan menjadi hasil setelahnya menyelesaikan pembelajaran?

f) Apa yang akan menjadi kriteria dalam mengevaluasi pembelajaran?

3) Langkah ketiga dalam pembelajaran SDL, peserta didik melaksanakan apa yang sudah direncanakan di langkah pertama, peserta didik memulai proses belajar mulai dari mengumpulkan materi belajar, mengerjakan tugas sampai pada evaluasi akhir

4) Langkah keempat adalah hasil dari proses pembelajaran. Berupa pengembangan keterampilan, akan tetapi yang utama adalah kepuasan diri peserta didik selama proses belajar. (Joshi, Bharat, 2012)

5) Langkah kelima pembelajaran SDL adalah terkait dengan evaluasi secara keseluruhan proses pembelajaran. Proses 
evaluasi ini dilakukan dalam dua langkah; pertama, evaluasi dilakukan pada setiap langkah SDL dan kedua itu terjadi pada langkah terakhir proses pembelajaran. Proses evaluasi ini dilakukan sesuai dengan kriteria yang telah ditentukan sebelumnya oleh peserta didik. Seluruhnya proses evaluasi dilakukan oleh peserta didik. Kepuasan diri peserta didik adalah hal utama dalam seluruh proses evaluasi. Tujuan tercapai atau tidak, diputuskan oleh peserta didik. Berikut gambar proses pembelajaran SDL.

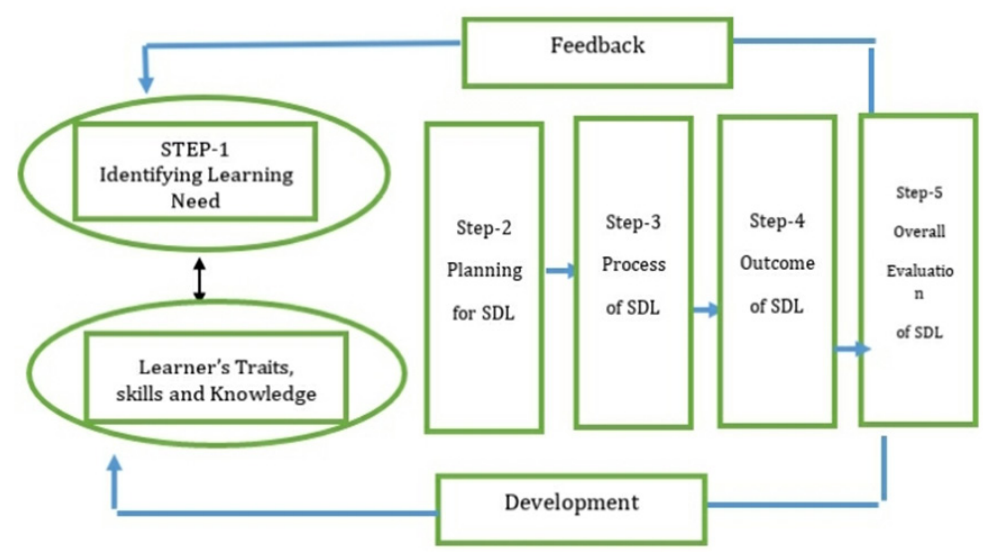

Gambar 1. Proses Pembelajaran SDL

Dapat ditarik sebuah kesimpulan bahwa dikembangkannya belajar mandiri untuk meningkatkan tanggung jawab peserta didik dalam proses pembelajaran. Tanggung jawab yang terbentuk dalam diri peserta didik akan menumbuhkan motivasi instrisik. Dengan adanya motivasi instrisik pada diri peserta didik akan membantu peserta didik dalam membuat pilihan informasi dan mengambil tanggung jawab untuk memutuskan apa yang akan dilakukan selama proses belajar hingga tercapainya tujuan pembelajaran yang diharapkan. 
192 | Elya Umi Hanik

\section{b. Konsep Literasi Digital}

Menurut Paul Gilster dalam bukunya yang berjudul Digital Literacy, literasi digital diartikan sebagai kemampuan untuk memahami dan menggunakan informasi dalam berbagai bentuk dari berbagai sumber yang sangat luas yang diakses melalui piranti komputer. Bawden menawarkan pemahaman baru mengenai literasi digital yang berakar pada literasi komputer dan literasi informasi. Literasi komputer berkembang pada dekade 1980-an, ketika komputer mikro semakin luas dipergunakan, tidak saja di lingkungan bisnis, tetapi juga di masyarakat. Namun, literasi informasi baru menyebar luas pada dekade 1990-an ketika informasi semakin mudah disusun, diakses, disebarluaskan melalui teknologi informasi berjejaring. Dengan demikian, mengacu pada pendapat Bawden, literasi digital lebih banyak dikaitkan dengan keterampilan teknis mengakses, merangkai, memahami, dan menyebarluaskan informasi. Konsep literasi digital, sejalan dengan terminologi yang dikembangkan oleh UNESCO pada tahun 2011, literasi digital merupakan kecakapan (life skills) yang tidak hanya melibatkan kemampuan menggunakan perangkat teknologi, informasi, dan komunikasi, tetapi juga kemampuan bersosialisasi, kemampuan dalam pembelajaran, dan memiliki sikap, berpikir kritis, kreatif, serta inspiratif sebagaikompetensi digital. Sementara itu, Douglas A.J.

Belshaw dalam tesisnya What is 'Digital Literacy'?mengatakan bahwa ada delapan elemen esensial untuk mengembangkan literasi digital, yaitu sebagai berikut:

1. Kultural, yaitu pemahaman ragam konteks pengguna dunia digital;

2. Kognitif, yaitu daya pikir dalam menilai konten;

3. Konstruktif, yaitu reka cipta sesuatu yang ahli dan aktual;

4. Komunikatif, yaitu memahami kinerja jejaring dan komunikasi di dunia digital; 
5. Kepercayaan diri yang bertanggung jawab;

6. Kreatif, melakukan hal baru dengan cara baru;

7. Kritis dalam menyikapi konten; dan

8. Bertanggung jawab secara sosial.

Aspek kultural, menurut Belshaw, menjadi elemen terpenting karena memahami konteks pengguna akan membantu aspek kognitif dalam menilai konten. (Kemendikbud, 2017). Dari beberapa pendapat di atas dapat disimpulkan bahwa literasi digital merupakan pengetahuan dan kecakapan untuk menggunakan media digital, alat-alat komunikasi, atau jaringan dalam menemukan, mengevaluasi, menggunakan, membuat informasi, dan memanfaatkannya secara sehat, bijak, cerdas, cermat, tepat, dan patuh hukum dalam rangka membina komunikasi dan interaksi dalam kehidupan sehari-hari.

Literasi digital melibatkan lebih dari sekadar kemampuan untuk menggunakan perangkat lunak atau mengoperasikan perangkat digital; tetapi juga terkait dengan keterampilan kognitif, motorik, sosiologis, dan emosional yang kompleks, yang dibutuhkan pengguna dalam hal ini peserta didik agar dapat berfungsi secara efektif di lingkungan digital. Literasi digital dapat didefinisikan sebagai keterampilan bertahan hidup di era digital. Dengan menggunakan berbagai jenis literasi digital, peserta didik dapat meningkatkan proses belajar mereka dan "bertahan" dari berbagai hambatan dalam pembelajaran (Eshet-Alkalai, 2004).

Literasi digital sebagai rangkaian gerakan melek media yang dirancang untuk meningkatkan kontrol individu terhadap media yang mereka gunakan untuk mengirim dan menerima pesan. Kata kunci dari penting nya media literasi yaitu bagaimana kita memiliki filter atau kontrol terhadap media yang bisa digunakan untuk pencarian informasi dan hiburan. Landasan hukum perlu diperkenalkan sebagai pengetahuan bahwa kegiatan media literasi dilindungi oleh undang undang dasar. Ruang lingkup dari media literasi antar lain literasi teknologi, literasi informasi, 
literasi tanggung jawab dan kompetensi. Pengetahun akan literasi tekhnologi disesuaikan dengan teori determinasi tekhnologi yang mengatakan bahwa masyarakat dalam kehidupannya mengikuti perkembangan teknologi (Silvana \& Darmawan, 2018). Dalam dunia pendidikan, makna pendidikan melalui media, yaitu, penggunaan media sebagai sumber daya atau tambahan didaktik untuk perbaikan proses belajar mengajar. Pendidikan dengan memanfaatkan media sangatlah penting. Hal ini menjadi salah satu alternatif untuk membentuk peserta didik yang kritis (Galán, 2015).

Dalam hal ini, tedapat komponen utama literasi digital yaiitu berkenaan dengan keahlian apa saja yang wajib dimiliki dalam menggunakan komunikasi dan teknologi informasi. Steve Wheeler dalam tulisannya yang berjudul Digital Literacies for Engagement in Emerging Online Cultures (Wheeler, 2013), mencatat ada sembilan komponen utama dalam dunia literasi digital, yaitu: 1) Social Networking, munculnya berbagai macam media sosial merupakan salah satu gambaran yang terdapat pada Social Networking atau sering disebut juga fenomena social online. Saat ini setiap manusia yang bersinggungan dalam kehidupan maya akan selalu bertemu dengan fasilitas tersebut. Gadget yang dimiliki oleh seseorang bisa dipastikan mempunyai berbagai macam akun sosial media, misalnya: Google+, Instagram, Path, Linkedin, Twitter, maupun Facebook. Menggunakan fasilitas social media diharapkan memiliki sifaf selektif dan berhati-hati. Oleh sebab itu perlu memahami dan mengusai tujuan-tujuan dari setiap tampilan yang dimiliki. Disisi lain perlu memperhatikan etika dalam menggunakan situs media sosial. Literasi digital menunjukkan bagaimana cara untuk menggunakan media sosial dengan baik. 2) Tramsliteracy. Transliteracy dimaknai sebagai keahlian menggunakan semua yang berlainan terutama untuk menciptakan konten, menghimpun, menyebarluaskan sampai membicarakan lewat beberapa media sosial, kelompok diskusi, gadget dan semua fasilitas online yang ada. 3) Maintaning 
Privacy. Hal utama dari literasi digital yaitu tentang menjaga diri dalam kehidupan online. Mempelajari dari semua cybercrime seperti kejahatan di dunia maya melalui kartu ATM dan kartu kredit, memahami karakteristik situs yang tidak nyata (palsu), kejahatan melalui email dan lain sebagainya. 4) Managing Digital Identity, ini berhubungan dengan bagaimana prosedur memakai tanda pengenal yang sesuai di beberapa situs media sosial dan platformnya yang lain. 5) Greating Content, hal ini berhubungan dengan suatu keahlian tentang prosedur menciptakan isi di beberapa fasilitas situs dunia maya dan platformnya, sebagai contoh: Blog, Prezi, Wikis, PowTon. 6) Organising and Sharing Content, yaitu mengelola dan mendistribusikan isi berita supaya lebih gampang dibagikan. 7) Reusing/repurposing Content. Mampu bagaimana menciptakan isi dari berbagai jenis informasi yang tersedia hingga memproduksi konten baru dan bisa dipakai kembali untuk beberapa kebutuhan. 8) Filtering and Selecting Content. Keahlian menelusur, memilah dan menyaring berita secara pas sesuai dengan hal-hal yang diinginkan dan dibutuhkan, seperti melalui beberapa alamat URL di situs internet. 9) Self Broadcasting, ini mempunyai tujuan untuk mendistribusikan gagasan-gagasan yang baru atau ide personal da nisi multimedia, seperti lewat Wkis, Forum atau Blog. Hal tersebut merupakan jenis partisipasi di dunia may (Mustofa \& Budiwati, 2019).

Adapun dalam pengembangan literasi digital perlu memperhatikan prinsip- prinsip dasar, diantarnya;

1) Pemahaman

Prinsip pertama dari literasi digital adalah pemahaman sederhana yang meliputi kemampuan untuk mengekstrak ide secara implisit dan ekspilisit dari media.

2) Saling Ketergantungan

Prinsip kedua dari literasi digital adalah saling ketergantungan yang dimaknai bagaimana suatu bentuk media berhubungan dengan yang lain secara potensi, 
metaforis, ideal, dan harfiah. Dahulu jumlah media yang sedikit dibuat dengan tujuan untuk mengisolasi dan penerbitan menjadi lebih mudah daripada sebelumnya. Sekarang ini dengan begitu banyaknya jumlah media, bentuk-bentuk media diharapkan tidak hanya sekadar berdampingan, Dahulu jumlah media yang sedikit dibuat dengan tujuan untuk mengisolasi dan penerbitan menjadi lebih mudah daripada sebelumnya. Sekarang ini dengan begitu banyaknya jumlah media, bentuk-bentuk media diharapkan tidak hanya sekadar berdampingan, tetapi juga saling melengkapi satu sama lain.

3) Faktor Sosial

Berbagi tidak hanya sekadar sarana untuk menunjukkan identitas pribadi atau distribusi informasi, tetapi juga dapat membuat pesan tersendiri. Siapa yang membagikan informasi, kepada siapa informasi itu diberikan, dan melalui media apa informasi itu berikan tidak hanya dapat menentukan keberhasilan jangka panjang media itu sendiri, tetapi juga dapat membentuk ekosistem organik untuk mencari informasi, berbagi informasi, menyimpan informasi, dan akhirnya membentuk ulang media itu sendiri.

4) Kurasi

Berbicara tentang penyimpanan informasi, seperti penyimpanan konten pada media sosial melalui metode "save to read later" merupakan salah satu jenis literasi yang dihubungkan dengan kemampuan untuk memahami nilai dari sebuah informasi dan menyimpannya agar lebih mudah diakses dan dapat bermanfaat jangka panjang. Kurasi tingkat lanjut harus berpotensi sebagai kurasi sosial, seperti bekerja sama untuk menemukan, mengumpulkan, serta mengorganisasi informasi yang bernilai. (Kemendikbud, 2017). 
Pendekatan yang dapat dilakukan pada literasi digital mencakup dua aspek, yaitu pendekatan konseptual dan operasional. Pendekatan konseptual berfokus pada aspek perkembangan koginitif dan sosial emosional, sedangkan pendekatan operasional berfokus pada kemampuan teknis penggunaan media itu sendiri yang tidak dapat diabaikan.

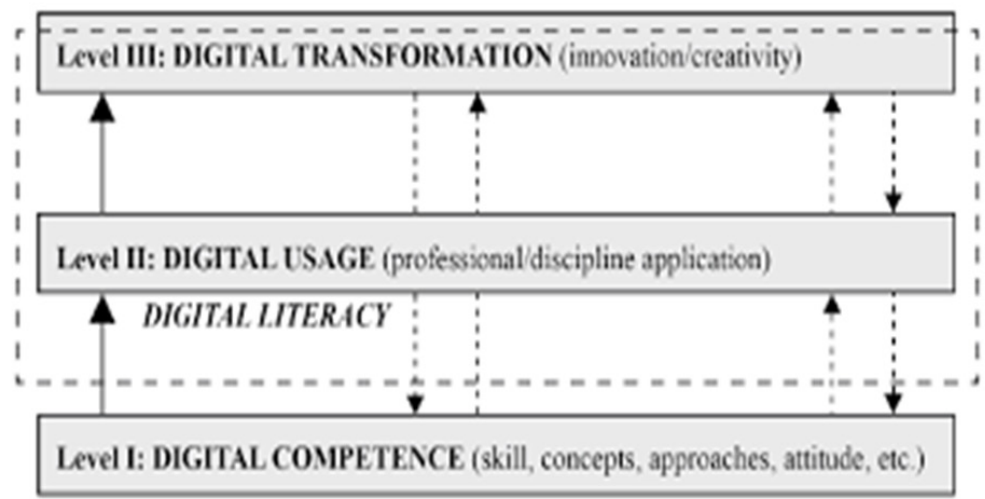

Gambar 2. Prinsip Pengembangan Literasi Digital

Prinsip pengembangan literasi digital menurut Mayes dan Fowler (2006) bersifat berjenjang. Terdapat tiga tingkatan pada literasi digital. Pertama, kompetensi digital yang meliputi keterampilan, konsep, pendekatan, dan perilaku. Pada level 1 mencakup perbedaan tingkat keterampilan Individu atau kelompok yang memanfaatkan kompetensi digital sesuai dengan situasi kehidupan mereka, kompetensi digital dapat dikuasai pada tingkat keahlian bervariasi dari keterampilan dasar hingga kompetensi evaluatif atau analitis. Kedua, penggunaan digital yang merujuk pada pengaplikasian kompetensi digital yang berhubungan dengan konteks tertentu. Pada level II Literasi digital harus melibatkan keberhasilan penggunaan kompetensi digital dalam situasi kehidupan, penerapan kompetensi digital yang sesuai dalam konteks situasi atau domain tertentu, memunculkan kebermanfaatan penggunaan digital untuk individu, grup, atau organisasi. Ketiga, transformasi digital yang 
membutuhkan kreativitas dan inovasi pada dunia digital. Tahap akhir adalah transformasi digita dapat dicapai ketika penggunaan digital dikembangka dengan inovasi dan kreativitas,sehingga merangsang perubahan signifikan dalam bidang profesional atau pengetahuan dalam konteks pribadi maupun sosial. Perubahan ini dapat terjadi pada tingkat individu, atau pada kelompok atau organisasi. Suatu persyaratan dalam transformasi adalah refleksi kritis. (Martin, 2009)

Dalam perkembangannya, literasi digital yang kemudian diadaptasi oleh dunia pendidikan dan Badan Penelitian dan Pengembangan Kementerian Pendidikan dan Kebudayaan Republik Indonesia mengemukakan bahwa literasi dasar menjadi salah satu komponen kecakapan abad XXI dalam pendidikan khususnya pada kurikulum 2013. literasi dasar terdiri atas literasi: 1)bahasa dan sastra, 2) numerasi, 3)sains, 4)informatika dan teknologi, 5) finansial, dan 6) budaya dan kewarganegaraan (Balitbang Kemendikbud, 2017). Dikembangkannya enam jenis literasi dasar tersebut sebagai upaya agar warga masyarakat Indonesia memiliki keterampilan abad XXI menjadi manusia yang memiliki kemampuan berpikir kritis, krearif, komunikatif dan kolaboratif serta berkarakter. Sebagai dasar dalam mencapaian tujuan yang tercanang dalam membangun generasi emas Indonesia tahun 2045.

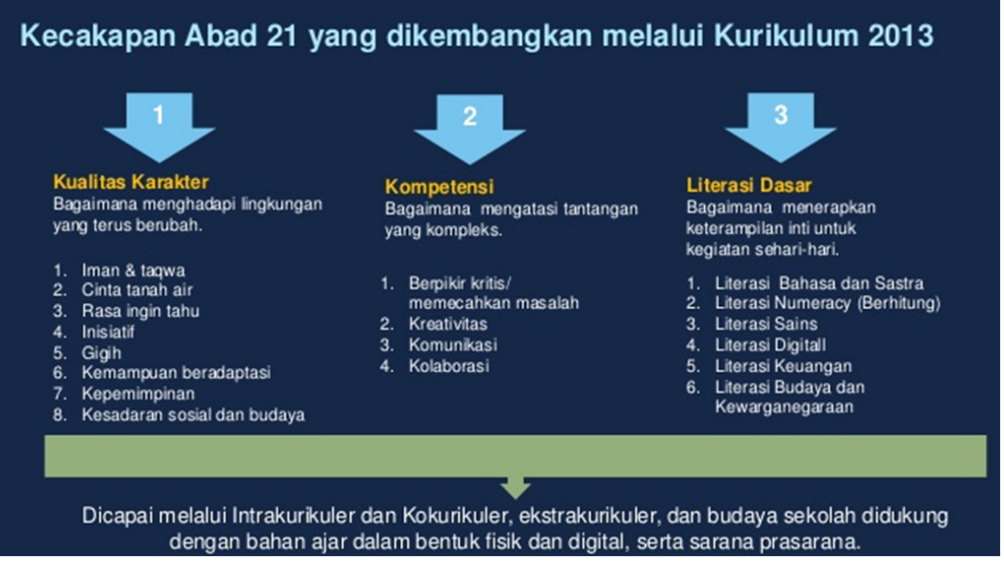

Gambar 3. Kecapakan Abad 21 dalam Kurikulum 2013

Elementary Vol. 8 No. 1 Januari - Juni 2020 
Proses pendidikan literasi digital seyogyanya diawali sejak usia dini, wajib ada tatacara pendidikan literasi digital yang terstruktur. Adapun proses tersebut melaui beberapa tahapan, yaitu: 1) Gerakan literasi digital di keluarga, disini harus bisa menentukan asaran gerakan literasi gigital di keluarga dan mempunya strategi gerakan literasi digital di keluarga. Strategi tersebut meliputi: penguatan kapasitas faslititator, peningkatan jumlah dan ragam Sumber belajar bermutu, perluasan akses sumber belajar bermutu. 2) Literasi digital dalam gerakan literasi sekolah, ada tiga hal yang harus diperhatikan, yaitu: Pertama, mengkondisikan lingkungan fisik ramah literasi. Kedua, mengupayakan lingkungan sosial dan afektif sekolah sebagai medel komunikasi dan interaksi yang literat. Ketiga, mengupayakan sekolah sebagai lingkungan akademik yang literat. 3) Gerakan literasi digital di masyarakat, disini harus bisa menentukan asaran gerakan literasi gigital di masyarakat dan mempunya strategi gerakan literasi digital di masyarakat, ada beberapa yang harus dilakukan, yaitu: Pertama, pelatihan penggunaan aplikasi ataup perangkat digital. Kedua, pelatihan penggunaan perangkat atau aplikasi internet yang bijaksana. Ketiga, sosialisasi bahan referensi tentang hukum dan etika dalam menggunakan media digital. (Mustofa \& Budiwati, 2019).

\section{c. Analisis Self Directed Learning Berbasisi Literasi Digital Pada Masa Pandemi Covid-19 Di Madarasah Ibtidaiyah.}

Dalam masa pandemi Covid-19 yang sedang dialami oleh berbagai Negara di dunia, telah berdampak besar pada berbagi aspek kehidupan. Hal ini juga dirasakan oleh Negara Indonesia, akibat pandemi Covid-19 ini, salah satunya pada aspek pendidikan. Dengan berlakunya surat Edaran Nomor 4 tahun 2020 tentang pelaksanaan Kebijakan Pendidikan dalam Masa Darurat Corona Virus Disease, yang berisi tentang enam hal penting yaitu perubahan dalam pelaksanaan pendidikan di Indonesia, diantaranya terkait dengan 1) kebijakan pelaksanaan 
200 | Elya Umi Hanik

Ujian Nasional (UN), 2) Proses Belajar dari Rumah, 3) Ujian Sekolah untuk kelulusan, 4) Kenaikan Kelas, 5) Penerimaan Peserta Didik Baru (PPDB), dan 6) Dana Bantuan Operasional Sekolah atau Bantuan Operasionai Pendidikan. Adanya kebijakan baru tersebut, tentunya mengubah arah pendidikan di Indonesia sebagai bagian penyesuaian situasi dan kondisi masa pandemi.

Salah satu point penting dari keenam kebijakan baru tersebut adalah, pelaksanaan belajar dari rumah. Adapun kebijakan belajar dari rumah memiliki ketentuan diantaranya;

1) Belajar dari Rumah melalui pembelajaran daring/jarak jauh dilaksanakan untuk memberikan pengalaman belajar yang bermakna bagi siswa, tanpa terbebani tuntutan menuntaskan seluruh capaian kurikulum untuk kenaikan kelas maupun keluiusan;

2) Belajar dari Rumah dapat difokuskan pada pendidikan kecakapan hidup antara lain mengenai pandemi Covid-19;

3) Aktivitas dan tugas pembelajaran Belajar dari Rumah dapat bervariasi antarsiswa, sesuai minat dan kondisi masingmasing, termasuk mempertimbangkan kesenjangan akses/ fasilitas belajar di rumah;

4) Bukti atau produk aktivitas Belajar dari Rumah diberi umpan baiik yang bersifat kualitatif dan berguna dari guru, tanpa diharuskan memberi skor/ nilai kuantitatif (Mendikbud RI, 2020).

Kebijakan pembelajaran daring yang dianjurkan pemerintah bukanlah tanpa suatu alasan, pemerintah sudah mempertimbangkan bahwa pembelajaran daring menjadi solusi pembelajaran yang sesuai pada masa pandemi saat ini, fakta tersebut juga diperkuat oleh data hasil survey, yang dilansir dari website theconversation.com, telah menunjukkan hasil surveiyang melibatkan 682 responden dari beberapa perguruan tinggi negeri dan juga swasta di Pulau Jawa, Sumatra, Sulawesi, Kalimantan, Maluku, dan Papua, riset selama bulan April dengan menyebar 
survei online ke seluruh Indonesia. Lebih dari 70\% dari responden adalah mahasiswa (71\%), sisanya adalah dosen (16\%), dan sisanya adalah petinggi universitas. Mayoritas responden (94\%) mengapresiasi dengan baik keputusan manajemen perguruan tinggi dalam melakukan pembelajaran melalui metode daring selama pandemi (Elisabeth Rukmini, 2020). Dari hasil data survey tersebut tentunya bisa diadaptasi pada semua jenjang pendidikan di Indonesia, tidak hanya pada tingkat Universita saja. Selain itu terdapat pertimbangan dari segi kebermanfaatan pemilihan pembelajaran daring secara online memiliki beberapa kelebihan yaitu Mengatasi persoalan jarak dan waktu, Mendorong sikap belajar aktif, Membangun suasana belajar baru, Memudahkan pemutakhiran bahan ajar bagi guru pendidik, Mengakomodasi berbagai gaya belajar, dan meningkatkan kesempatan untuk belajar bagi peserta didik dengan menawarkan pengalaman virtual dan alat-alat yang menghemat waktu mereka, sehingga memungkinkan mereka belajar lebih lanjut.(Pusvyta Sari, 2015). Dari kajian tersebut, pembelajaran daring secara online bisa dikembangkan dalam perubahan arah pembelajaran saat ini.

Melihat ketentuan belajar dari rumah yang telah ditetapkan oleh menteri pendidikan dan kebudayaan tersebut, pendidik haruslah memastikan kegiatan belajar mengajar tetap berjalan, meskipun tanpa tatap muka dengan peserta didik. Oleh karenanya dibutuhkan sebuah inovasi pembelajaran di tengah masa pandemi. Perubahan arah pendidikan dari teacher centered menjadi student centered manjadi dasar proses pembelajaran jarak jauh, dimana pembelajaran yang dilaksanakan lebih menekankan pada bagaimana keaktifan peserta didik dalam mencari pengalaman baru dalam proses belajar tanpa dibatasi ruang dan waktu.

Sejalan dengan problematika yang ada, pembelajaran self directed learning hadir sebagai langkah solutif dalam kegiatan belajar pada kondisi sekarang ini. Konsep pembelajaran self directed learning didasari oleh teori pendidikan konstruktivisme Vygotsky, yang menyatakan bahawa pengetahuan bukanlah 
sesuatu yang given dari alam karena hasil kontak manusia dengan alam, tetapi pengetahuan merupakan hasil konstruksi (bentukan) aktif manusia itu sendiri (Prof Dr. Suyono, 2012), Hal ini dapat diartikan bahwa pembelajar atau peserta didik mengkonstruk sendiri pengetahuannya, peserta didik tidak lagi dipandang sebagai sesuatu yang pasif melainkan memiliki tujuan. Point penting dalam teori konstruktivisme adalah self regulated learner, peserta didik dapat mengelola diri sendiri dan bertanggung jawab pada proses pembelajaran, peserta didik dikembangkan menjadi seorang yang memiliki pengetahuan tentang strategi belajar yang sesuai pada diri peserta didik. Desain belajar yang demikian tentunya juga bisa diimplementasikan pada peserta didik di Madrasah Ibtidaiyah, karena sesuai dengan karakteristik kognitif peserta didik pada jenjang ini, yaitu tahap operasional konkret, dimana pada tahap ini, pikiran logis anak mulai berkembang dan peserta didik sudah mampu berpikir secara operasi konkret.

Dalam mengimplementasikan pembelajaran self directed learning di Madarasah Ibtidaiyah diharapkan peserta didik akan tumbuh kemampuan diri yang mencakup; self motivation, self management, self monitoring dan self modification. self motivation berkaitan dengan persiapan diri dan motivasi awal peserta didik sebelum melaksankan pembelajaran, tanggungjawab pesertadidik dalam melaksanakan tugas dan merencanakan pembelajaran. Self management, mengontrol bagaimana berperilaku, dan menyelesaikan masalah dengan kreatif dan membuat sebuat keputusan mandiri. Self monitoring berkaitan dengan refleksi diri dan evaluasi diri yang selama proses pembelajaran. Adapun self modification berkaitan dengan perubahan perilaku sebagai akibat dari self monitoring dan feedback yang diterima. 


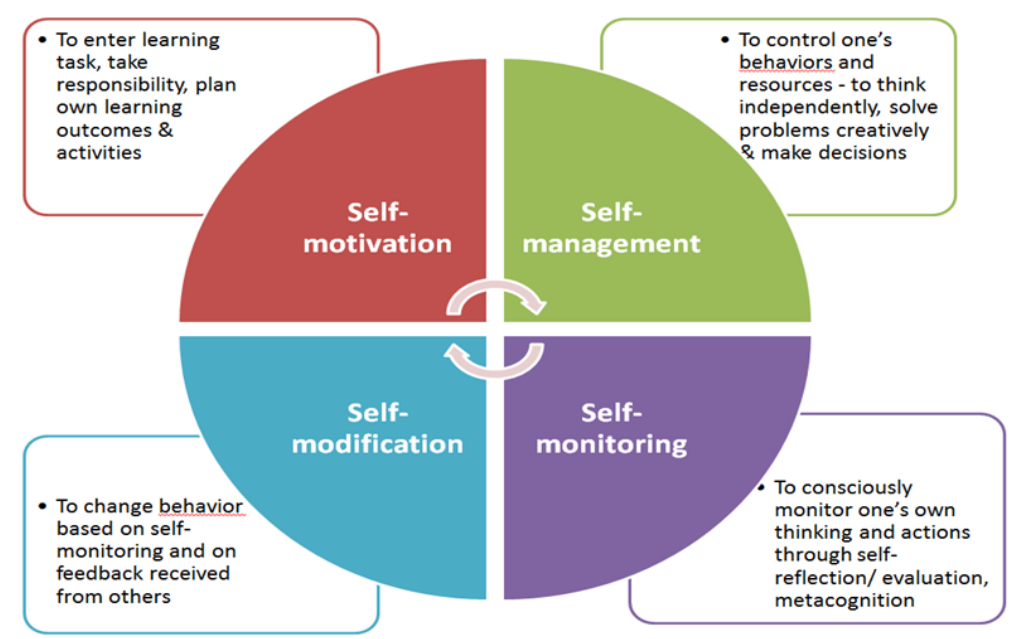

Gambar 4. prinsip pembelajaran SDL

Pelaksanaan pembelajaran Selfdirected learning bagi peserta didik di Madrasah yang diterapkan pasa masa pandemi ini, dapat dikolaborasikan dengan memanfaatkan media digital sebagai sarana untuk memudahkan peserta didik dalam pembelajaran, sejalan dengan pembelajaran digital yang diharapkan pada era 4.0 sekarang ini. Pembelajaran mandiri selama di rumah, yang dilaksanakan peserta didik bukan hanya belajar mandiri tanpa tujuan yang jelas, akan tetapi belajar mandiri yang terprogam dan terarah. Dalam hal ini, sebagai pendidik dan orang tua bisa mengarahkan peserta didik untuk memanfaatkan peran literasi digital sebagai bahan atau media dalam mencapai tujuan selama proses belajar mandiri.

Strategi yang bisa diimplementasikan dalam pelaksanaan pembelajaran self direct learning berbasis litersi digital ini, diantaranya;

1) Penyediaan Situs-Situs Edukatif sebagai Sumber Belajar Warga Sekolah

Situs edukatif dapat digunakan oleh seluruh warga sekolah, diantaranya menggunakan situs edukatif yang dapat mengembangkan pembelajaran pengetahuan 
204 | Elya Umi Hanik

diri diantaranya; rumah belajar kemendikbud, google suite education, kelas pintar, quipper school, ruang guru, sekolahmu, zenius. Dengan mengakses situs edukatif tersebut peserta didik dengan mudah bisa menentukan sendiri bahan dan materi pembelajaran tanpa dibatasi ruang dan waktu, hal ini tentunya mendukung pembelajaran peserta didik yang dilakukan di rumah selama masa pandemi Covid-19.

2) Penggunaan Aplikasi-Aplikasi Edukatif sebagai Sumber Belajar Warga Sekolah

Aplikasi-aplikasi edukatif yang bisa digunakan oleh warga sekolah adalah Jelajah Seru, Anak Cerdas, 101 lagu Anak-Anak, Kumpulan Dongeng, dan sebagainya. Pendidik dan orang tua dapat mengarahkan peserta didik untuk menggunakan aplikasi- aplikasi tersebut untuk menambah pengetahuan dan kreativitas. Pendidik juga dapat mengaitkan aplikasi-aplikasi tersebut dalam pembelajaran(Kemendikbud, 2017).

Selaian kedua strategi tersebut, pemerintah dalam hal ini melalui Menteri pendidikan dan kebudayan Indonesia, juga telah mempersiapkan pembelajaran daring dengan membuat progam belajar dari rumah yang ditayangkan melalui saluran TV Nasional Republik Indonesia atau TVRI. Hal tersebut menjadi satu alternatif belajar mandiri bagi peserta didik yang memiliki keterbatasan pada akeses internet, karena kondisi ekonomi ataupun letak geografis. Lembaga penyiaran publik TVRI akan menyiarkan program belajar dari rumah selama kurang lebih tiga bulan, dengan program materi belajar untuk Sekolah Dasar (SD), Sekolah Menengah Pertama (SMP), Sekolah Menengah Atas (SMA), pelajaran umum dan parenting. Melalui beberapa upaya tersebut, diharapkan proses belajar mandiri berbasis literasi digital dapat dirasakan nilai kebermanfaatannya bagi peserta didik pada masa pandemi ini serta dapat menghasilkan capaian pembelajaran yang 
tetap berkualitas meskipun dilaksnakan secara mandiri belajar di rumah.

Pada tahap akhir pelaksanaan belajar mandiri berbasis litersi digital adalah adanya evaluasi. Sesuai dengan karakateristik psikologi anak sekolah dasar, bahwa belajar mandiri yang dimaksudkan bukan sepenuhnya dilaksankan secara mandiri tanpa suatu pengawasa ataupun bantuan orang lain. Akan tetapi dalam hal ini pendidik dan orang tua masih menjalankan tugas scaffolding, atau mediated learning, pemberi dukungan tahap demi tahap oleh pendidk dan orang tua selama proses pembelajaran, sebagai pengontrol, dan evaluator yang berperan memberikan penguatan atau feedback bahwa pembelajaran yang dilaksankan sudah terlaksana dengan baik ataupun masih ada kekurangan.

\section{Simpulan}

Berdasarkan rumusan masalah dan pembahasan yang telah diuraikan pada bab sebelumnya, dapat disimpulkan hasil penelitian ini, sebagai berikut;

1. Pembelajaran self directed learning adalah belajar mandiri untuk meningkatkan tanggung jawab peserta didik dalam proses pembelajaran.

2. Literasi digital adalah pengetahuan dan kecakapan untuk menggunakan media digital, alat-alat komunikasi, atau jaringan dalam menemukan, mengevaluasi, menggunakan, membuat informasi, dan memanfaatkannya secara sehat, bijak, cerdas, cermat, tepat, dan patuh hukum dalam rangka membina komunikasi dan interaksi dalam kehidupan sehari-hari

3) Implementasikan pelaksanaan pembelajaran self direct learning berbasis litersi digital pada masa pandemi Covid-19, sebagai berikut; Penyediaan Situs-Situs Edukatif sebagai Sumber Belajar Warga Sekolah seperti, Penggunaan AplikasiAplikasi Edukatif sebagai Sumber Belajar Warga Sekolah dan pembelajaran daring dengan membuat progam belajar dari rumah yang ditayangkan melalui saluran TV Nasional Republik Indonesia. 
206 | Elya Umi Hanik

\section{DAFTAR PUSTAKA}

Elisabeth Rukmini. (2020). Online learning sebagai masa depan pendidikan tinggi Indonesia selepas pandemi. Mei 12, 2020 $3.11 \mathrm{pm}$ WIB.

Eshet-Alkalai, Y. (2004). Digital Literacy: A Conceptual Framework for Survival Skills in the Digital era. Journal of Educational Multimedia and Hypermedia, 13(1),93-106

Galán, J. G. (2015). Media education as theoretical and practical paradigm for digital literacy an interdisciplinary analysis. European Journal of Science and Theology, 11(3), 1-10

Joshi, Bharat, M. N. D. (2012). Perspective of Self-directed Learning (SDL). An International Multidisciplinary Peer Reviewed E Journal.

Kayacan, K., \& Ektem, I. S. (2019). The effects of biology laboratory practices supported with self-regulated learning strategies on students' self-directed learning readiness and their attitudes towards science experiments. European Journal of Educational Research, 8(1),313 - 323.

Kemendikbud. (2017). Materi Pendukung Literasi Sains. Gerakan Literasi Nasional,

Martin, A. (2009). Digital literacy for the third age: Sustaining identity in an uncertain world. ELearning Papers, 12(February), 1-15.

Mendikbud RI. (2020). Surat Edaran Nomor 4 Tahun 2020 Tentang Pelaksanaan Kebijakan Pendidikan Dalam Masa Darurat Penyebaran Coronavirus Disease (COVID-19). 
Mustofa, M., \& Budiwati, B. H. (2019). PROSES LITERASI DIGITAL TERHADAP ANAK: Tantangan Pendidikan di Zaman Now. Pustakaloka, 11(1), 114.

Plews, R. C. (2017). Self-Directed in Online Learning. International Journal of Self-Directed Learning, 1(14), 37-57.

Prof Dr. Suyono, H. (2012). Belajar dan Pembelajaran Teori dan Konsep Dasar. PT Remaja Rosdakarya.

Pusvyta Sari. (2015). Memotivasi Belajar Dengan Menggunakan E-Learning. Ummul Quro, 6(Jurnal Ummul Qura Vol VI, No 2, September 2015), 20-35

Richard, B. R. (2007). Self-Directed Learning: A Process Perspective. , 4(1): 53-64

Silvana, H., \& Darmawan, C. (2018). Pendidikan Literasi Digital Di Kalangan Usia Muda Di Kota Bandung. Pedagogia, 16(2), 146.

Song, L \& Hill, J. R. (2007). A Conceptual Model for Understanding Self-Directed Learning in Online Environments. Journal of Interactive Online Learning, 1(6), 27-42.

Tan, L., \& Koh, J. (2014).In Self-directed learning: Learning in the 21st century education.

Wheeler, S. (2013). Digital literacies for engagement in emerging online cultures. ELC Researcj Paper Series, 5, 14-25. 
208 | Elya Umi Hanik

Zamnah, L. N., \& Ruswana, A. M. (2018). Penerapan Model Pembelajaran Self-Directed Learning untuk Meningkatkan Kemampuan Pemahaman Matematis Mahasiswa. JPMI (Jurnal Pendidikan Matematika Indonesia), 3(2), 52. 